American Journal of Biochemistry and Biotechnology 2 (3): 111-118, 2006

ISSN 1553-3468

(C) 2006 Science Publications

\title{
Effective Thermophilic Composting of Crop Residues for Inactivation of Tobacco Mosaic Virus
}

\author{
${ }^{1}$ A. E.Ghaly, ${ }^{1}$ F. Alkoaik, ${ }^{1}$ A. Snow and ${ }^{2}$ R. Singh \\ ${ }^{1}$ Biological Engineering Department, Dalhousie University, Halifax, Nova Scotia, Canada B3J 2K9 \\ ${ }^{2}$ Potato Research Center, AAFC-ACC, 850 Lincoln Road, Fredericton, New Brunswick, Canada E3B 4Z7
}

\begin{abstract}
An effective thermophilic composting bioreactor, in which a homogenous distribution of temperature was maintained at $63-65^{\circ} \mathrm{C}$ by the addition of a bioavailable carbon and low mixing, was developed. The bioreactor operated on a mixture of tomato plant residues-wood shavings-municipal solid waste compost infected with tobacco mosaic virus (TMV). The initial $\mathrm{C}$ : $\mathrm{N}$ ratio and moisture content of the compost mixture were adjusted to $30: 1$ and $60 \%$, respectively. The composting process was successful in destroying the tobacco mosaic virus. The results showed that the ability of the untreated virus (inoculum) to infect tobacco plants $\left(150 \mathrm{LL} \mathrm{L}^{-1}\right)$ was much higher than its ability to infect tomato plants $\left(22 \mathrm{LL} \mathrm{L}^{-1}\right)$. The TMV completely lost its ability to infect the leaves of susceptible hosts (tobacco and tomato plants) after $96 \mathrm{hrs}$ of controlled thermophilic $\left(63-65^{\circ} \mathrm{C}\right)$ composting (or $126 \mathrm{~h}$ from the start of the composting process). Semilog plots of the ratio of the infection ability of the surviving virus to that of the initial inoculum (as measured by the number of local lesions) were developed. The decimal reduction time (the time necessary to reduce the infection ability of TMV by $1-\log$ or $90 \%$ ) was found to be 62.4 and $109.7 \mathrm{hrs}$ for tobacco and tomato plants, respectively. The relatively short time required for complete inactivation of TMV in this study was achieved as a result of the extension of the thermophilic stage and maintaining a constant high temperature with a uniform temperature distribution by the continuous addition of the proper amount of bioavailable carbon (used cooking oil) and low mixing.
\end{abstract}

Key words: TMV, compost, thermophilic, temperature, inactivation, tomato remains

\section{INTRODUCTION}

Greenhouse tomato production represented $58 \%$ of the greenhouse total vegetable production in Canada in 2000 , with a production area of 1550 hectares, yielding 182,736 tonnes $^{[1]}$. Typical vegetable greenhouse operations produce 40-60 tonnes of organic residues per hectare per year, as a result of trimming and harvesting the crop, which must be disposed of properly ${ }^{[2]}$. Tomato crop is susceptible to various types of insects and diseases under greenhouse environments where optimum conditions of most pathogens are met. The most common insects are aphids, whiteflies, leafminers, tomato pinworms, armyworms, tomato fruitworm and cabbage looper. Insects, in addition to the damage caused by feeding on the plant, can spread bacterial, fungal and viral tomato diseases and provide infestation sites for others ${ }^{[3,4]}$. The spore forming bacterium Bacillus cereus, the fungi Pythium Fusarium, Cladosporium, Botrytis, Alternaria and Phytophthora and the viruses tomato yellow curl and tobacco mosaic are among the most reported plant pathogens affecting tomato crops under greenhouse conditions ${ }^{[5]}$. However, viruses cause the most damaging tomato diseases and can reduce plant yield by $70-100 \%{ }^{[6]}$. The most common sources of virus inoculum are the debris of infected plants which serve as reservoirs for virus transmission to healthy plants ${ }^{[7,8]}$. Therefore, improper disposal of these plant residues can contribute to recycling of plant pathogens ${ }^{[9]}$.

Composting of greenhouse wastes has been considered by $\mathrm{NSDAFF}^{[10]}$ and $\mathrm{ODAF}^{[2]}$ as the preferred organic waste management method, especially for the destruction of plant pathogens. Composting is the aerobic biological decomposition of organic matter ${ }^{[11,12]}$, whose end product (compost) can be used to restore and preserve the environment ${ }^{[13]}$. It converts the unstable organic materials into a more stable form that is safer to use for improving soil fertility, tilth and water holding capacity ${ }^{[14]}$. In addition, composting reduces the volume of organic material to be spread, improves its handling properties and reduces odor, flies and pathogens ${ }^{[15]}$.

Most bacterial and fungal plant pathogens are sensitive to heat with the exception of spore forming Bacillus cereus and a few species of Fusarium oxysporum, which are considered heat resistant ${ }^{[16-18]}$. However, the tobacco mosaic virus (TMV) is considered the most heat resistant plant pathogen and it

Corresponding Author: A.E.Ghaly, Biological Engineering Department, Dalhousie University, Halifax, Nova Scotia, Canada B3J 2K9, Tel: 902494-6014, Fax: 902423-2423 
has been known to survive for more than 50 years in dried plant parts ${ }^{[7,8,18]}$. Therefore, a thermal process that is capable of destroying TMV will certainly destroy other plant pathogens.

The aim of this study was to evaluate the effectiveness of a controlled thermophilic composting process of TMV infected tomato plant residues in eradicating the virus. The specific objectives were to: (a) infect healthy tomato plants with TMV and identify the virus in infected plants using an ELISA test, (b) test the ability of the system to extend the thermophilic phase and maintain a constant temperature, (c) evaluate the success of the TMV inactivation process using an ELISA test, (d) test the ability of the inactivated TMV virus (compost) to infect susceptible host plants and (d) determine the virus survival rate and the time required for total inactivation.

\section{MATERIALS AND METHODS}

The composting system shown in Fig. 1 consisted of a frame, three bioreactors (each with a mixing unit and an air supply unit) and data acquisition system. The frame was made of aluminum sheets and angles (3.2 $\mathrm{mm}$ thick). It held the mixing motors, flow meters, air and exhaust gas manifolds, tubing and the thermocouple wires. A detailed description of the frame can be found in Alkoaik ${ }^{[19]}$.

Each bioreactor (Fig. 2) was constructed of 520 $\mathrm{mm}$ long and $203 \mathrm{~mm}$ (ID) polyvinyl chloride (PVC) tube having a wall thickness of $5 \mathrm{~mm}$. A removable circular Plexiglas plate of $203 \mathrm{~mm}$ diameter and $6 \mathrm{~mm}$ thickness was recessed and secured into one side of the cylinder by means of six stainless steel screws $(6 \mathrm{~mm})$. A rubber gasket lining $(2.5 \mathrm{~mm}$ thick o-ring) was added to the inner side of the circular plate to keep it tight. There was a small circular window $(64 \mathrm{~mm}$ in diameter) on the removable circular plate, which was closed with a rubber stopper (No.13) and used as a sampling port. A PVC plate of $203 \mathrm{~mm}$ diameter and 6 $\mathrm{mm}$ thickness was glued into the other side of the tube. Each reactor was fitted into an aluminum ring, which was fastened into the frame by means of four bolts $(6$ $\mathrm{mm}$ ) and nuts. A removable $10.5 \mathrm{~mm}$ diameter solid stainless steel shaft (having 5 stainless steel collars in which five bolts of $69 \mathrm{~mm}$ length and $6 \mathrm{~mm}$ diameter each were mounted) was mounted on two bearings inside each bioreactor. The shaft was rotated $(5.76 \mathrm{rpm})$ by a thermally protected electric motor (Model No. 127P1486/B, D. C., Sigma Instruments Inc., Braintree, Mass, USA). There were three holes at the bottom and one at the top of the bioreactor, which were drilled and threaded to take a $12 \mathrm{~mm}$ nylon hose barb. The holes at the bottom were connected to a manifold by $6.4 \mathrm{~mm}$ diameter Tygon tubing and used for aeration, whereas the one at the top was used for the exhaust gas. Air was supplied continuously to the bottom of the bioreactor from the laboratory air supply. It passed through a pressure regulator and a pressure gage (to maintain the pressure around $5 \mathrm{kPa}$ ) and then through a water bath (to humidify the inlet air to nearly $100 \%$ saturation) and finally through a flow meter (Model 32461-14, ColeParmer Instrument Company, Vernon Hills. Illinois. USA) capable of measuring a flow in the range of $0.0566-0.566 \mathrm{~m}^{3} \mathrm{~h}^{-1}$. Both circular plates were insulated with $38.1 \mathrm{~mm}$ thick Styrofoam layer, while the tube was insulated with 38.1-mm thick Fiberglass.

The data acquisition system consisted of a master unit (Multiscan 1200, Omega, Stamford, CT, USA), a thermocouple scanning card having 24 isolated differential input channels (MTC/24, Omega, Stamford, $\mathrm{CT}$, USA), software, type $\mathrm{T}$ (copper-constantan) temperature sensors (Cole Parmer, Chicago, IL, USA), a personal computer (IBM Pentium IV) and a printer (Hewlett Packard Laser Jet 4). The master unit was connected to a computer via RS 232 interface. Three thermocouples were located at the bottom of the bioreactor and were used to measure the temperature of the compost mass whereas the fourth was located at the top of the bioreactor, near the outlet air exit $(21 \mathrm{~mm}$ away) and was used to measure the temperature of the exhaust gas. Thermocouple locations, on the bottom of all bioreactors, were chosen to be $65 \mathrm{~mm}$ from the inlet air.

Compost mixture preparation: The materials used in this study included tomato plant residues, wood shavings, municipal solid waste compost, urea and used cooking oil. Some characteristics of these materials are shown in Table 1. The tomato plant residues, wood shavings and municipal solid waste compost contained sufficient macro and micro nutrients. The used cooking oil and wood shavings had very high $\mathrm{C}: \mathrm{N}$ ratios, while the tomato plant residues and municipal solid waste compost had low $\mathrm{C}: \mathrm{N}$ ratios. The tomato plant residues (leaves, stems and some fruits) were collected from a greenhouse at an average moisture content of approximately $90 \%$ and left over night at room temperature $\left(\approx 25^{\circ} \mathrm{C}\right)$ to partially dry (MC $\left.76 \%\right)$. They were then chopped into small pieces using a shredder (Model 242A645-515, 5HP, Briggs and Stratton, Plainfield, NJ, USA), mixed with wood shavings (1: 1.5 dry basis) and finally ground in a hammer mill (Model $\mathrm{C}-\mathrm{H}$, Horvick Manufacturing, NCC, Moorhead, Minnesota, USA) to an average size of $6.0 \mathrm{~mm}$. A 15day old municipal solid waste compost was added to the tomato trimmings mixture in order to introduce a wide range of active composting microorganisms. Urea [CO $\left(\mathrm{NH}_{2}\right)_{2}$ ] was used as a nitrogen source $(46 \%$ nitrogen) to adjust the $\mathrm{C}$ : $\mathrm{N}$ ratio to $30: 1$. Used cooking oil was used as a bioavailable carbon source. The heat balance performed on the system showed total heat losses of $51.2 \mathrm{~kJ} \mathrm{~h}^{-1}\left[{ }^{[19]}\right.$. Since used cooking oil has an energy content of $36 \mathrm{~kJ} \mathrm{~mL}^{-1}$, it was decided to add 18 $\mathrm{mL}$ every $12 \mathrm{hrs}\left(1.46 \mathrm{~mL} \mathrm{~h}^{-1}\right)$ to compensate for the heat losses from the system, extend the length of the thermophilic stage and maintain the temperature at $63^{\circ} \mathrm{C}$. 
Am. J. Biochem. \& Biotech., 2 (3): 111-118, 2006

Table 1: Some characteristics of tomato plant residues, wood shaving and municipal solid waste compost

\begin{tabular}{|c|c|c|c|c|}
\hline Characteristics & Tomato plant residues & Wood shavings & Municipal compost & Used cooking oil \\
\hline Moisture Content (\%) & 76.0 & 8.0 & 58.6 & NA \\
\hline \multicolumn{5}{|c|}{ Total solids (TS) $\left(\mathrm{mg} \mathrm{g}^{-1} \mathrm{DM}\right)$} \\
\hline Volatile solids (VS) & 693.0 & 997.4 & 854.6 & 999.45 \\
\hline Ash & 307.0 & 2.6 & 145.4 & 0.55 \\
\hline \multicolumn{5}{|l|}{ Nitrogen $\left(\mathrm{mg} \mathrm{g}^{-1} \mathrm{DM}\right)$} \\
\hline Total Kjeldahl Nitrogen & 27.0 & 1.0 & 18.0 & 0.22 \\
\hline Ammonium Nitrogen & 2.2 & 0.2 & 5.2 & 0.004 \\
\hline \multicolumn{5}{|l|}{ Carbon (mg g $\left.{ }^{-1} \mathrm{DM}\right)$} \\
\hline Total & 327.0 & 499.0 & 440.0 & 775.0 \\
\hline Organic & 260.0 & 390.0 & 350.0 & -- \\
\hline \multicolumn{5}{|c|}{ Elemental Composition $\left(\mathrm{mg} \mathrm{g}^{-1} \mathrm{DM}\right)$} \\
\hline $\mathrm{Ca}$ & 51.0 & 0.8 & 20.0 & 0.057 \\
\hline $\mathrm{Na}$ & 0.7 & 0.0 & 6.2 & 0.301 \\
\hline $\mathrm{Fe}$ & 0.4 & 0.0 & 2.8 & 0.14 \\
\hline $\mathrm{Mg}$ & 4.7 & 0.1 & 1.8 & 0.008 \\
\hline $\mathrm{Zn}$ & 0.0 & 0.0 & 0.1 & ND \\
\hline $\mathrm{K}$ & 57.6 & 0.6 & 7.8 & 0.01 \\
\hline $\mathrm{Cl}$ & 0.07 & 0.0 & 0.3 & 0.742 \\
\hline $\mathrm{P}$ & 10.5 & 0.0 & 2.7 & 0.01 \\
\hline $\mathrm{S}$ & 7.9 & 0.9 & 2.3 & 2.324 \\
\hline Others ${ }^{2}$ & 174.1 & 0.2 & 101.4 & 0.161 \\
\hline $\mathrm{C}: \mathrm{N}$ & 12.1: 1 & 499.0: 1 & 24.4: 1 & 3875.0: 1 \\
\hline
\end{tabular}

These values are the average of three replicates (the coefficient of variation (CV) varied from 1.1 to $6.9 \%$ ).

NA Not applicable

ND Not detectable

Volatile solids are the organic matter (largely carbon, oxygen and nitrogen) which are lost at $550^{\circ} \mathrm{C}$, leaving only the ash.

Others include mostly silica and other elements.

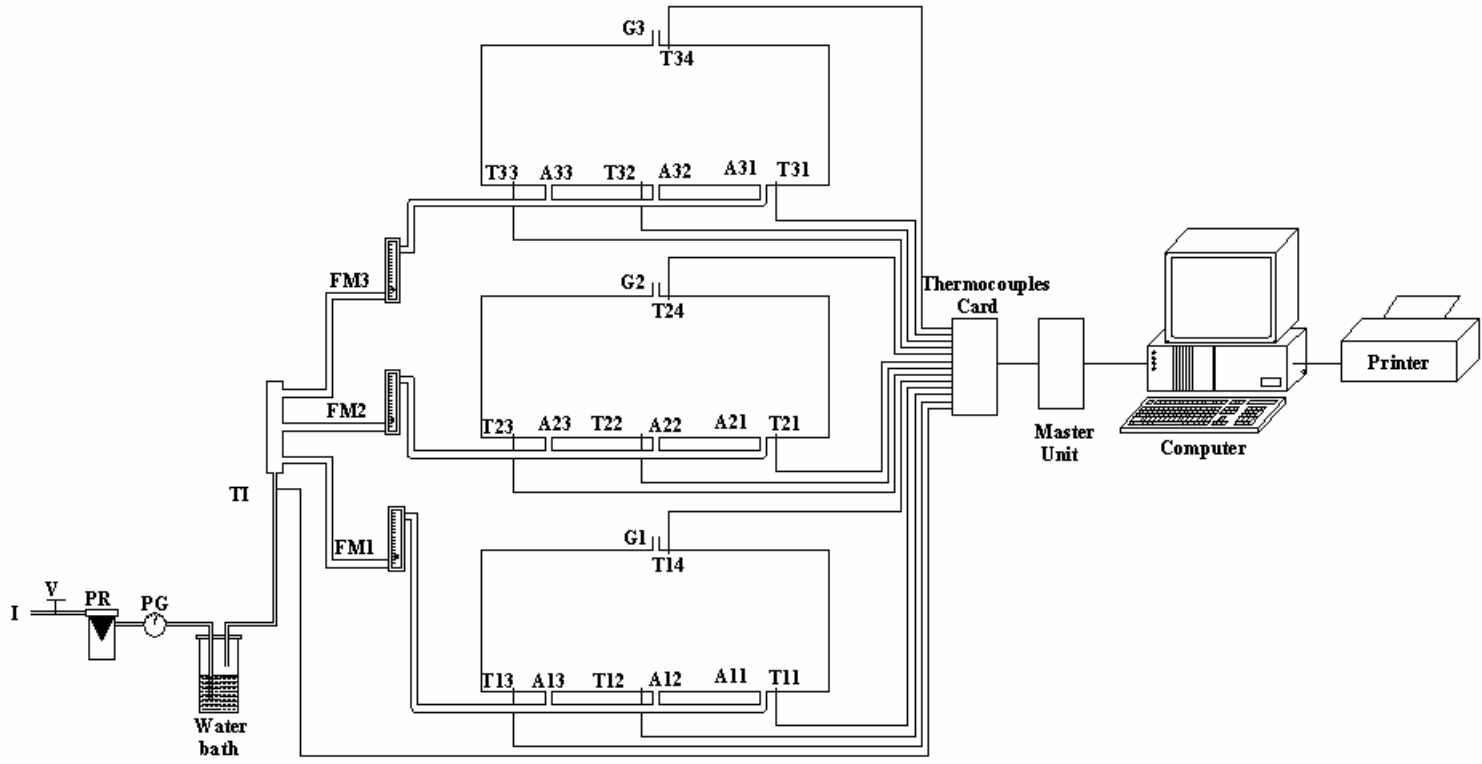

A-Inlet air ports, FM- Flow meter, G- Exhaust gas ports, I- Inlet air

PR- Pressure regulator, PG- Pressure gage, T- Thermocouple location, V- Valve

Fig. 1: In-vessel composting system

Infection of healthy tomato plants with virus: Tobacco mosaic virus (PV-1) was obtained from the American Type Culture Collection (ATCC, Manassas, VA). In order to ensure that the TMV virus was active, one hundred and twenty, 4-week-old individually grown tomato plants (thirty each of Golden Boy, Roma, Red Robin and Scotia varieties) were infected with the virus. The plants were obtained from a specialized local nursery. Each plant was transferred into a large round plastic pot $(12.5 \mathrm{~cm})$ using Miracle-Gro-garden Soil for Vegetables as a potting media (Scotts Company, Marysville, OH, USA) and placed in a growth chamber. The tomato plants were irrigated weekly with a solution of Miracle-Gro (Scotts Company, Marysville, $\mathrm{OH}$, USA) all Purpose water soluble plant fertilizer (Table 2 ) at the recommended rate of $4 \mathrm{~mL} \mathrm{~L}^{-1}$. 


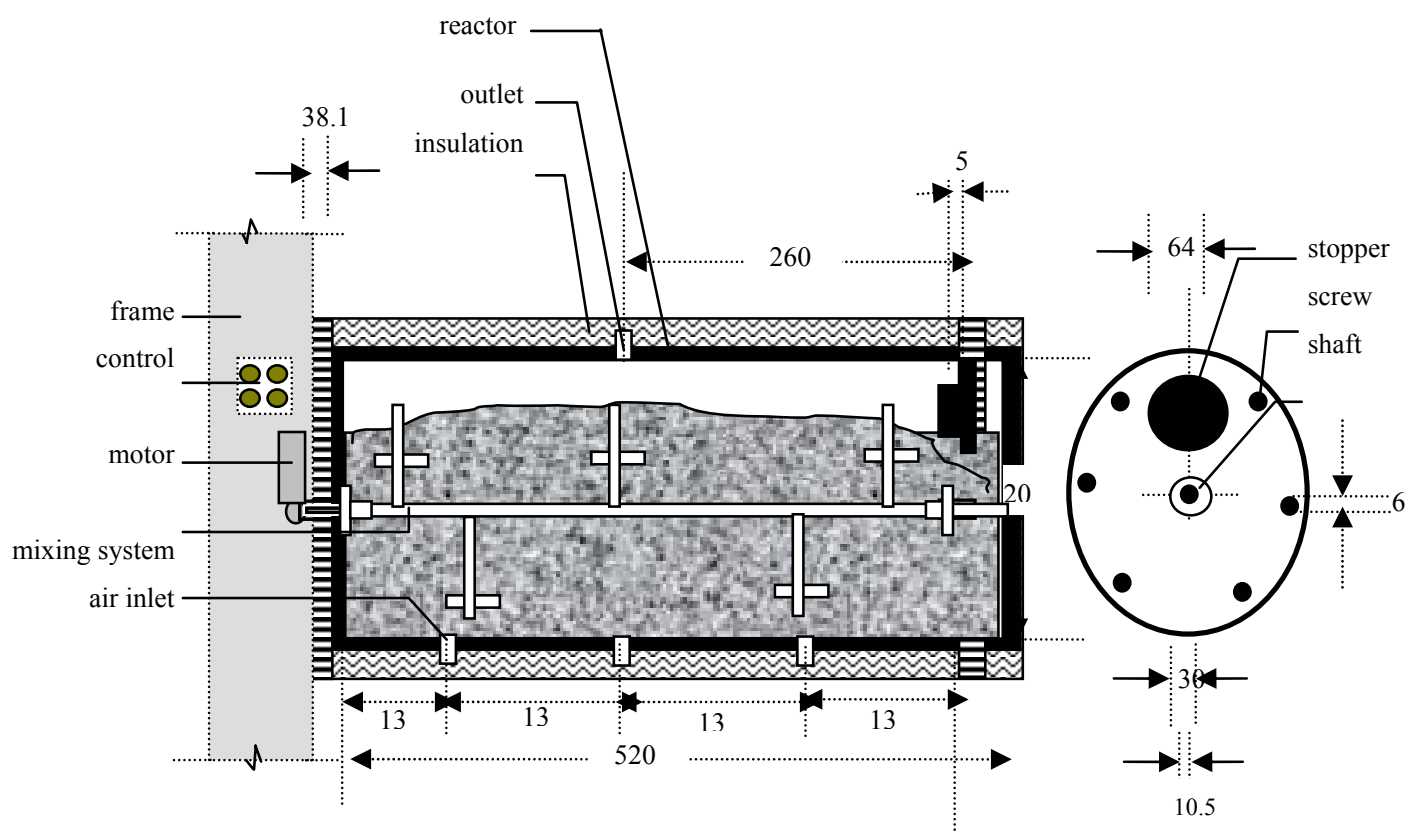

(a) cross-section

(b) side view

Fig. 2: Detailed schematic of the bioreactor

Table 2: Hydroponic fertilizer (Plant Products Co. Ltd., Brampton, Ontario, Canada)

\begin{tabular}{lc}
\hline Nutrient & Value \\
\hline Macronutrient Content (\%) & \\
$\mathrm{N}$ & 10.0 \\
$\mathrm{P}_{2} \mathrm{O}_{5}$ & 6.0 \\
$\mathrm{~K}_{2} \mathrm{O}$ & 16.0 \\
$\mathrm{Ca}$ & 7.2 \\
$\mathrm{Mg}$ & 2.2 \\
$\mathrm{~S}$ & 2.9 \\
$\mathrm{Micronutrient}$ Content (\%) & \\
$\mathrm{Fe}$ & 0.3000 \\
$\mathrm{Cu}$ & 0.0052 \\
$\mathrm{Mn}$ & 0.1042 \\
$\mathrm{Zn}$ & 0.0052 \\
$\mathrm{~B}$ & 0.0157 \\
$\mathrm{Mo}$ & 0.0105 \\
\hline
\end{tabular}

Tomato leaves were wetted and soil was soaked with the Miracle-Gro solution $\left(\sim 300 \mathrm{~mL}\right.$ pot $\left.^{-1}\right)$. Fresh water was added when needed to compensate for the water lost by evaporation. The photoperiod was kept at $12 \mathrm{hr}$ and the temperature was maintained in the range of 22 $\pm 2^{\circ} \mathrm{C}$. By the end of the first week of planting, tomato plants looked healthier and new leaves had developed.

The inoculation process illustrated in Fig. 3 was followed. The sealed TMV vial (contained freeze dried infected tissue) was carefully opened and the contents of the vial were placed in a pre-cooled $\left(4^{\circ} \mathrm{C}\right)$ mortar. A volume of $9 \mathrm{~mL}$ of the inoculation buffer $(0.1 \%$ peptone water, prepared by dissolving $1 \mathrm{~g}$ bactopeptone in $1 \mathrm{~L}$ deionized distilled water and then autoclaving at $121{ }^{\circ} \mathrm{C}$ and $103.4 \mathrm{kPa}$ for $45 \mathrm{~min}$ ) was added. A sterile pestle was used to thoroughly triturate the tissue. A few leaves on each young, healthy tomato plant were selected and marked. While one hand was used to support the leave to avoid over pressing, the other hand was used to mechanically damage some of the cells using abrasive cloth (240-J). Then, TMV inoculum was lightly rubbed onto the systemic host plants (tomato) using a sterile cotton swab. The infected tomato plants were labeled and left in their own individual containers under a $12 \mathrm{~h}$ light period in the growth chamber for the virus infection process to take place (incubation period).

Identification of virus in infected tomato plants: After ten days, the symptoms of infection (mosaic-like) started to develop. The symptoms are characterized by alternating patches of dark green (normal) and light green or yellowish colors on leaves. Dark green areas also appeared thicker and elevated giving the leaves a blister-like appearance ${ }^{[7]}$. The infected tomato plants were collected for virus identification according to the procedure illustrated in Fig. 4. Three infected tomato plants were selected at random and newly developed leaves $(\sim 1 \mathrm{~g})$ were removed from each plant. Each sample was homogenized with the buffer solution in a mortar and then left aside (few min) to settle. The positive and negative controls, supplied with the ELISA kit, were prepared according to the manufacturer (Neogen Europe Ltd., Auchincruive, Scotland, UK) procedure and kept in a freezer $\left(-10^{\circ} \mathrm{C}\right)$ for later analyses. Volumes of $100 \mu \mathrm{L}$ of each sample and controls were transferred into a microtitre plate. After the addition of probe, antigen and color substrate, the plate was scanned using an ELISA plate reader (BioRad Laboratories, Hercules, CA, USA). 
Inoculum preparation: After confirmation of infection by TMV, a mixture of the infected plants $(\sim 200 \mathrm{~g})$ was added to $500 \mathrm{~g}$ of the final compost mixture, throughly mixed and divided into small portions of $50 \mathrm{~g}$ each. Each portion was placed in a sachet $(7 \times 12 \mathrm{~cm})$ made of porous fabric (muslin mesh). Each sachet was placed in a zip-lock bag and kept in a refrigerator at $4{ }^{\circ} \mathrm{C}$ until required for the composting experiments.

Composting protocol: About $62 \mathrm{~mL}$ of used cooking oil was initially added to each $1.8 \mathrm{~kg}$ mixture of tomato residues: wood shavings: municipal solid compost (1:1.5: 0.28 ratio). Water was used to adjust the moisture content to $60 \%$. The $\mathrm{C}: \mathrm{N}$ ratio was adjusted to $30: 1$ by the addition of urea and the final mixture was mixed well. A single inoculum sachet of the plant pathogen, TMV was securely fixed to the mixing rod as shown in Fig. 5. The final compost mixture $(3.5 \mathrm{~kg})$ was then placed in the bioreactor. It occupied $75 \%$ of the total volume of the bioreacter (or $0.012 \mathrm{~m}^{3}$ ). The plexiglas side wall was put in place and visual inspection of the bioreactor was done to detect any leakage before placing the insulation cover on the side wall. The mixing unit was started at 5 RPM and the system was operated at a constant aeration rate of 0.15 $\mathrm{m}^{3} \mathrm{~h}^{-1}$ (0.17 volume per volume per min, vvm) during all experiments. The temperature was continuously monitored. Once the temperature peaked (after $31 \mathrm{~h}$ ), a volume of $18 \mathrm{~mL}$ of the used cooking oil was added every $12 \mathrm{~h}$ in order to maintain the temperature above $55{ }^{\circ} \mathrm{C}^{[19]}$. In order to maintain a constant temperature during the thermophilic phase, six bioreactors were used and samples were collected from each reactor at the end of the assigned treatment period to assess the inactivation of the TMV $(24,48,72,96,120$ and 144 hrs from the start of the thermophilic stage for reactors $1-6$, respectively). The experiment was repeated 3 times.

Identification of virus in composting material: The sachets of TMV infected material were retrieved from the bioreactors at a pre-determined time $(24,48,72,96$, 120 and $144 \mathrm{hrs}$ after the peak temperature had been reached in reactors 1-6, respectively). An ELISA test was performed on the samples to determine the presence of TMV. A local lesion bioassay was then performed on two susceptible hosts (tomato and tobacco) to check the infectious ability of the TMV. The inoculation procedure previously described was followed. Once the infected plants exhibited the mosaic-like symptoms, the number of lesions was counted.

\section{RESULTS AND DISCUSSION}

Tomato infection process: Tobacco mosaic virus is transmitted principally by mechanical inoculation ${ }^{[20]}$. Different varieties (Golden boy, Roma, Red Robin and
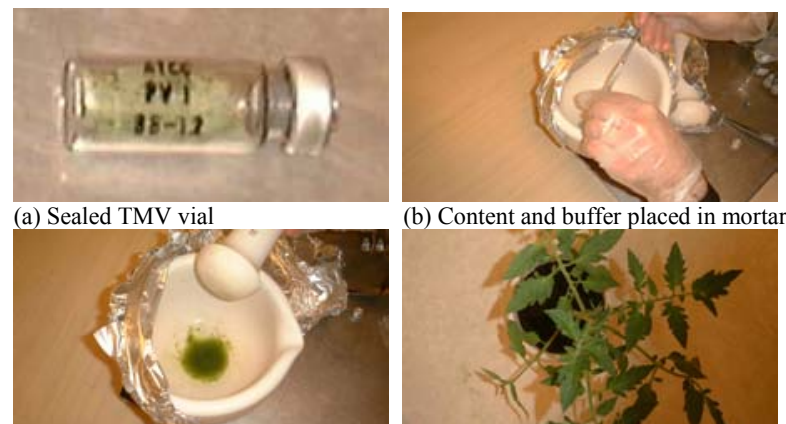
(b) Content and buffer placed in morta

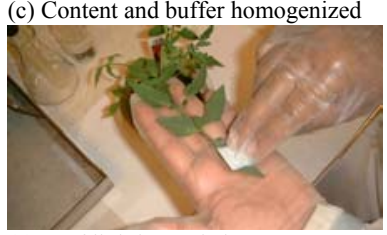

(e) Leaf lightly sanded

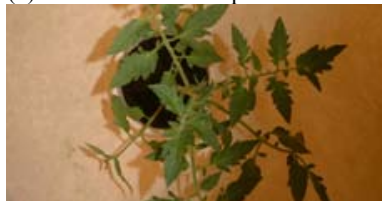

(d) Healthy tomato plant selected

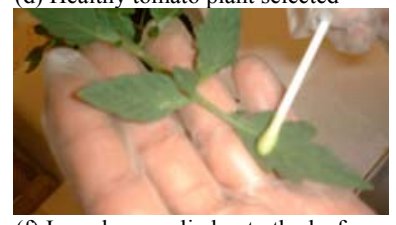

(f) Inoculum applied onto the leaf

Fig. 3: The TMV inoculation procedure
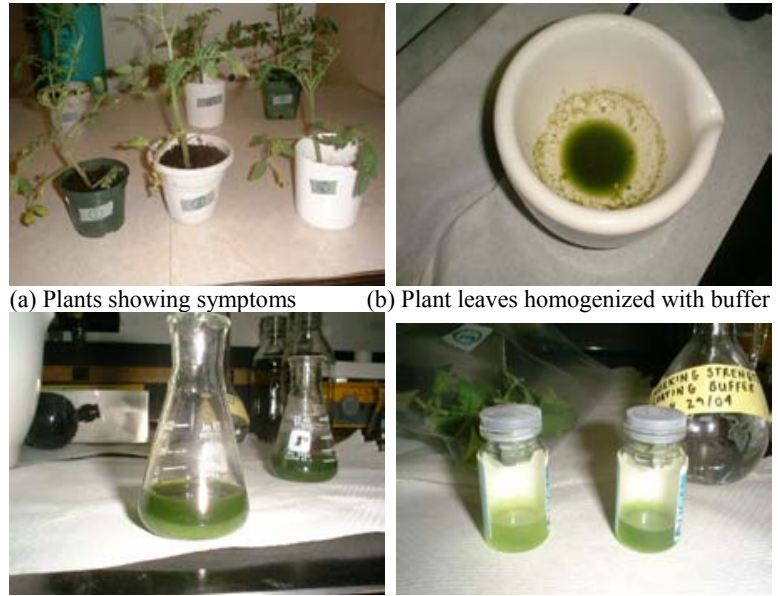

(c) Homogenized liquid left to settle
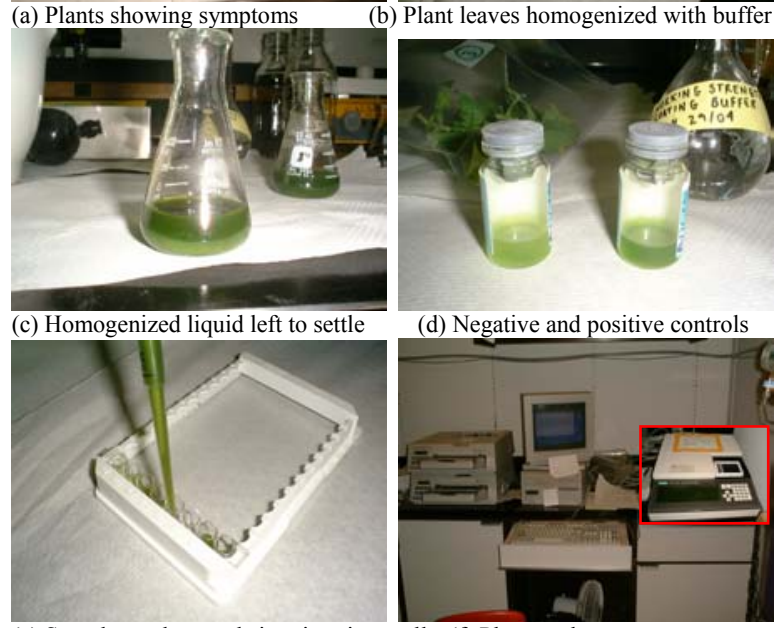

(d) Negative and positive controls

(e) Samples and controls in microtitre wells (f) Plate reader

Fig. 4: ELISA test procedure

Scotia) of tomato plants were inoculated and the infected plants were used to determine the fate of TMV during the thermophilic composting process. The infected tomato plants started to develop the TMV symptoms after 7-10 days. Samples of newly developed leaves of the inoculated tomato plants were tested for TMV infection using ELISA kit. The ELISA results shown in Fig. 6 indicated that all tomato samples were infected with TMV.

Temperature: The temperature profiles of TMV experiments are presented in Fig. 7. During all 


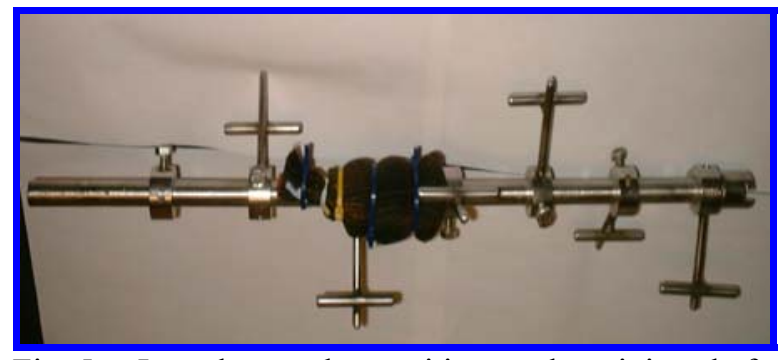

Fig. 5: Inoculum sachet position on the mixing shaft

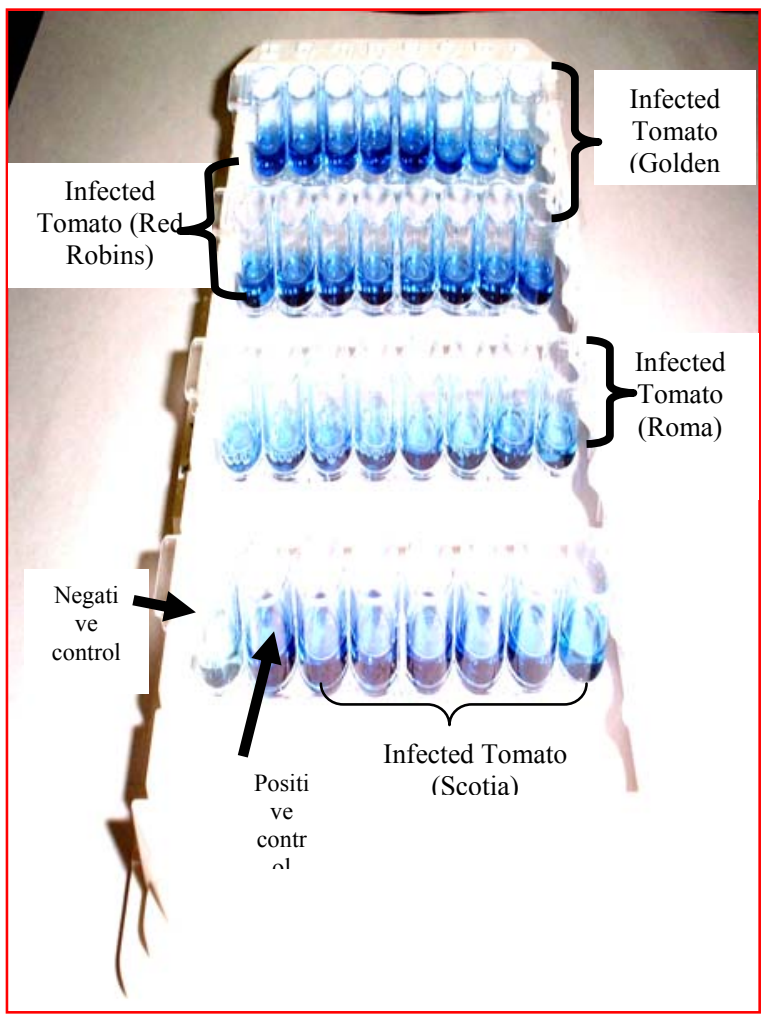

Fig. 6: ELISA test results of the infected samples

experiments, the average reactor temperature increased gradually reaching its peak after $31 \mathrm{hrs}$ of operation. Thermophilic temperatures in the range of $63.2-$ $64.9^{\circ} \mathrm{C}$ were maintained in all reactors $\left(63.3^{\circ} \mathrm{C} \pm 0.92\right.$ $\%, 63.2^{\circ} \mathrm{C} \pm 0.96 \%, 64.5{ }^{\circ} \mathrm{C} \pm 2.0 \%, 64.8{ }^{\circ} \mathrm{C} \pm 1.9 \%$, $64.9{ }^{\circ} \mathrm{C} \pm 1.7 \%$ and $64.9{ }^{\circ} \mathrm{C} \pm 1.7 \%$ for a duration of $24,48,72,96,120$ and $144 \mathrm{hrs}$ in the first, second, third, fourth, fifth and sixth reactors, respectively). These temperatures were maintained by the addition of used cooking oil as a bioavailable carbon source which compensated for the total energy loss from the system.

Assessment of virus inactivation: The retrieved samples were tested for the ability of the TMV virus to infect susceptible host plants (tobacco and tomato) using a local lesion bioassay. The local lesion bioassay performed on tobacco and tomato plants showed an initial concentration (infected, untreated material) of 150 and 22 local lesions/leaf ( $\mathrm{LL} \mathrm{L}^{-1}$ ), respectively. These were reduced to $35,12,2,0,0$ and $0 \mathrm{LL} \mathrm{L}^{-1}$ for

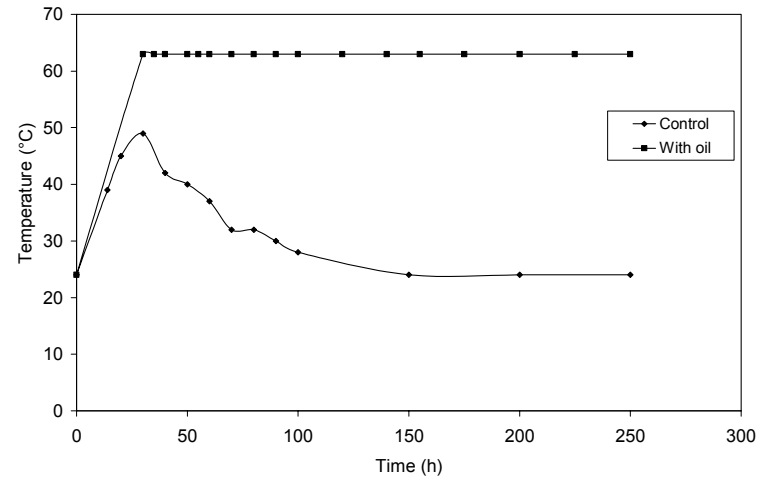

Fig. 7: Temperature profile for composting material

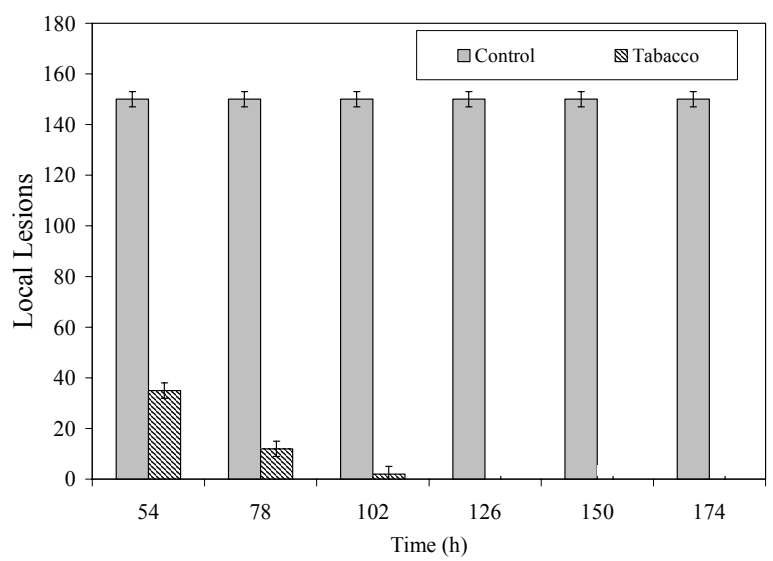

(a). Tobacco

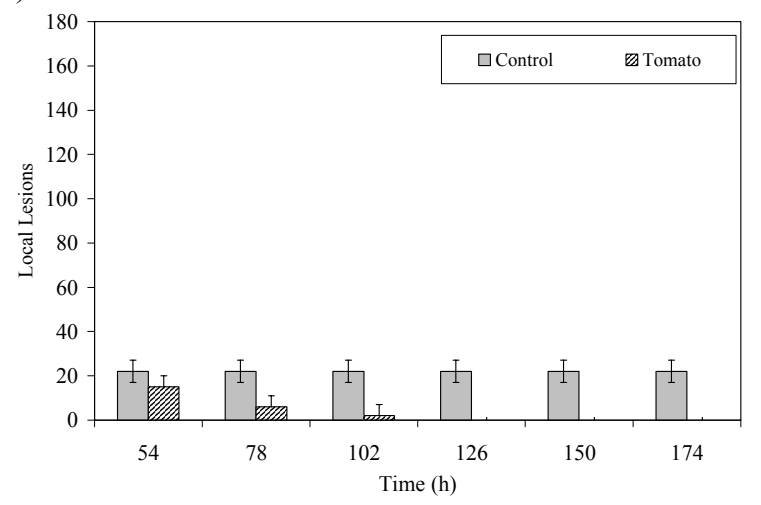

(b). Tomato

Fig. 8: TMV local lesions count

the tobacco plants and 15, 6, 2, 0, 0 and $0 \mathrm{LL} \mathrm{L}^{-1}$ for the tomato plants after 24, 48, 72, 96, 120 and $144 \mathrm{hrs}$ (from the time of temperature peak) of thermophilic treatment $\left(63.2-64.9^{\circ} \mathrm{C}\right)$. The results indicated that TMV completely lost its ability to infect the leaves of the two hosts after 4 days of thermophilic composting (Fig. 8).

Ryckeboer et al. ${ }^{[21]}$ investigated the fate of tobacco mosaic virus (TMV) during composting and found that TMV was significantly reduced (by a factor of three) after 19 days of composting at $58{ }^{\circ} \mathrm{C}$ and was reduced even further when the composting treatment was operated at $68{ }^{\circ} \mathrm{C}$ for 12 days. 
Bollen and Volker ${ }^{[22]}$ stated TMV is not completely inactivated in some composting systems and can be directly transmitted to plant roots without a vector. In the current study, TMV completely lost its ability to infect the leaves of a susceptible host after less than 4 days of controlled thermophilic composting and the compost material produced from this system is considered safe for land application. It should be noted that the controlled composting process has other advantageous destruction mechanisms beside high temperature such as microbial competition (antagonism) and toxicity of by-products $(\mathrm{pH}$, ammonia and organic acids) released as a result of plant residues decomposition that could inactivate TMV in a shorter time as reported by Lopez-Real and Foster ${ }^{[16]}$ and Bollen $^{[18]}$.

According to Hogland et al. ${ }^{[23]}$ and Ryckeboer et $a l .{ }^{[21]}$, the high temperature (about $60{ }^{\circ} \mathrm{C}$ ) that can be reached during the thermophilic stage of composting is the most important factor for inactivation of plant pathogens. However, temperature fluctuations, clumping of solids and improper mixing of raw material and amendment are the most negative characteristics of solid mixtures during composting process ${ }^{[11]}$. The inactivation period of TMV observed in the current study is significantly shorter than the two weeks reported by Marciniszyn and Gottschall ${ }^{[24]}$, the 21 days reported by Noble and Roberts ${ }^{[25]}$ and the 12 days at 68 ${ }^{\circ} \mathrm{C}$ reported by Ryckeboer et al. ${ }^{[21]}$. It was achieved as a result of extending the thermophilic phase and maintaining a constant high temperature in the bioreactor by the continuous addition of bioavailable source of carbon (used cooking oil) and the utilization of a continuous low mixing (5 RPM) that eliminated any temperature gradient in the composting system.

The relationship between number of local lesions (caused by the surviving virus) and composting time can be expressed by survival curves as shown in Fig. 9. Survival curves are semilog plots of the ratio of the concentration of surviving organisms to the initial number versus time. They are commonly used to interpret the inactivation kinetics of microorganisms. The destruction/inactivation of the TMV virus during the composting process can be described with the following first order equation:

$$
\frac{d N}{d t}=-k N
$$

Where:

$\mathrm{N}$ is the initial number of local lesions

$\mathrm{t}$ is the composting time (h)

$\mathrm{k} \quad$ is the decay constant $\left(\mathrm{h}^{-1}\right)$

The ability of the TMV virus to infect susceptible

hosts was tested using healthy tobacco and tomato plants. Although identical samples were used in both tests, the number of local lesions observed on the infected tobacco plants by the TMV virus from the untreated sample (initial) was much higher (150) then

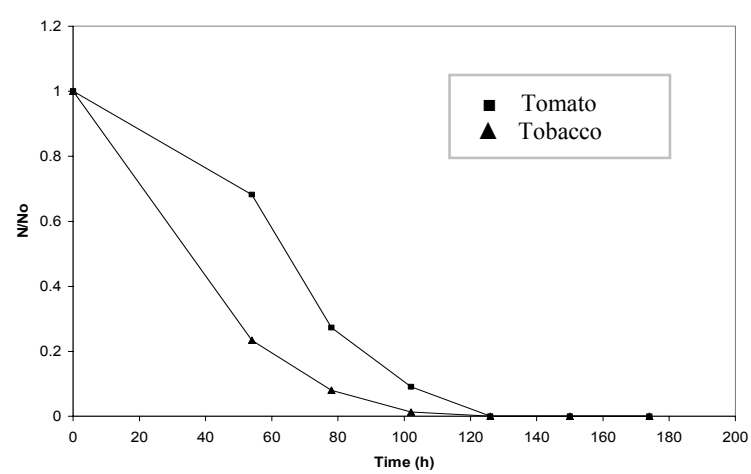

Fig. 9: Survival curves for TMV

the number of local lesions observed on the tomato plants infected with similar untreated sample. Therefore, equations 2 and 3 can be used to describe the ability of the TMV virus to infect different, susceptible hosts (tobacco and tomato) as a function of composting time and initial concentration.

$\frac{N}{N o}=e^{-0.0369 t}\left(R^{2}=0.93\right)$ for tobacco

$\frac{N}{N o}=e^{-0.021 t}\left(R^{2}=0.94\right)$ for tomato

From these equations, the decimal reduction time, which is defined in this study as the time necessary to reduce the infection ability of TMV by $1-\log$ or $90 \%$ at a given temperature was found to be equal to 62.40 and $109.65 \mathrm{hrs}$ for tobacco and tomato plants, respectively.

\section{CONCLUSION}

The results showed that the ability of the untreated virus (inoculum) to infect tobacco plants $\left(150 \mathrm{LL} \mathrm{L}^{-1}\right)$ was much higher than its ability to infect tomato plants $\left(22 \mathrm{LL} \mathrm{L}^{-1}\right)$. The controlled thermophilic composting process was successful in inactivating the tobacco mosaic virus. The TMV virus completely lost its ability to infect the leaves of susceptible hosts (tobacco and tomato plants) after less than four days of controlled thermophilic $\left(63-65^{\circ} \mathrm{C}\right)$ composting (or $126 \mathrm{~h}$ from the start of the composting process). Semilog plots of the ratio of the infection ability of the surviving virus to that of the initial inoculum (as measured by the number of local lesions) were developed. The decimal reduction time (the time necessary to reduce the infection ability of TMV by $1-\log$ or $90 \%$ ) was found to be 62.4 and $109.7 \mathrm{hrs}$ for tobacco and tomato plants, respectively. The relatively short time required for complete inactivation of TMV in this study was achieved as a result of extending the thermophilic stage and maintaining a constant high temperature with a uniform temperature distribution by the continuous addition of the proper amount of bioavailable carbon (used cooking oil) and low mixing. 


\section{ACKNOWLEDGEMENTS}

This research was funded by the National Science and Engineering Research Council (NSERC) of Canada. The financial support provided by the Government of Saudi Arabia is highly appreciated.

\section{REFERENCES}

1. AAFC, 2001. Profile of the Canadian Greenhouse Tomato Industry. Industry Highlights Report, Agriculture and Agri-Food Canada, Ottawa, Ontario.

2. ODAF, 2004. Best Management Practices. Ontario Department of Agriculture and Food. Horticultural Crops. Toronto, Ontario.

3. Sorensen, A.A., 1993. Constraints to the adoption of integrated pest management. Regional Producer Workshops, National Foundation for IPM Management Education, Austin, TX.

4. APS, 2006. Plant Pathology [online] Available: http://www.apsnet.org [2006, February 2]

5. Abu-Jawdah, Y.A., 1986. Diseases of tomatoes and cucumbers grown in greenhouses and their control. Ministry of Agriculture and Water. Ayyoubi Printers, Riyadh, Kingdom of Saudi Arabia.

6. Knapp, E. and D.J. Lewandowski, 2001. Tobacco mosaic virus, not just a single component virus anymore. Molecular Plant Pathol., 2: 117-123.

7. Pfleger, F.L. and R.J. Zeyen, 1991. Tomatotobacco mosaic virus disease [online] Available: http://www.extension.umn.edu/distribution/horticul ture/DG1 168.html [2006, January 14].

8. Zitter, T.A. and R. Provvidenti, 1984. Vegetable crops fact sheet. Department of Plant Pathology. Cornell University, Ithaca, NY.

9. Conway, K.E., 1996. An overview of the influence of sustainable agricultural systems on plant diseases. Crop Protection, 15: 223-28.

10. NSDAFF, 2004. Environmental guidelines for nursery and turf industry. Best Agricultural Waste Management Plans. Ministry of Agriculture, Food and Fisheries. Halifax, Nova Scotia.

11. Haug, R.T., 1993. The Practical Handbook of Composting Engineering. Lewis Publishers, Boca Raton, Florida.

12. Liang, C., K.C. Das and R.W. McClendon, 2003. The influence of temperature and moisture contents regimes on the aerobic microbial activity of a biosolids composting blend. Biores. Technol., 86: 131-137.

13. Stentiford, E.I., 1996. Composting Control: Principles and Practice. In: De Bertoldi, M. Sequi, P., Lemmes, B., Papi, T. (Eds), The Sciences of Composting. Blackie Academic and Professional, Glasgow, England.
14. Paré, T., H. Dinel and M. Schnitzer, 1999. Extractability of trace metals during co-composting of biosolids and municipal solid wastes. Biology and Fertility of Soils, 29: 31-37.

15. Murphy, D.W., 1991. Disease transfer studies in dead bird composter. Proc. Natl. Poultry Waste Management Symp. North Carolina State University, Raleigh, NC.

16. Lopez-Real, J. and M. Foster, 1984. Plant Pathogen Survival during the Composting of Agricultural Organic Wastes., pp: 291-299. In: J.K.R. Glasser (Eds.) Composting of Agricultural and Other Wastes. Elsevier Applied Science Publishers, New York, NY.

17. Bollen, G.J., 1985. Lethal Temperatures Of Soil Fungi. In: Ecology and Management of Soil-Borne Plant Pathogens, C.A. Parker, A.D. Rovira, K.J. Moore and P.T.W. Wong (Eds). APS, St. Paul, $\mathrm{MN}$.

18. Bollen, G.J., 1993. Factors Involved in Inactivation of Plant Pathogens during Composting of Crop Residues. In: Hoitink, H.A.J. and K.M. Keener (Eds.). The Science and Engineering of Composting. Ohio State University, Columbus, $\mathrm{OH}$.

19. Alkoaik, F., 2005. Fate of plant pathogens and pesticides during composting of greenhouse tomato plant residues. Unpublished $\mathrm{Ph}$. D. thesis, Dalhousie University, Halifax, Nova Scotia, Canada.

20. Ryckeboer, J., S. Cops and J. Coosemans, 2002. The fate of plant pathogens and seeds during anaerobic digestion and aerobic composting of source separated household wastes. Compost Science and Utilization, 10: 204-216.

21. Lojek, J.S. and G.B. Orlob, 1972. Transmission of tobacco mosaic virus by Myzus persicae. J. Gen. Virol., 17: 125-127.

22. Bollen, G.J. and D. Volker, 1996. Phytohygienic Aspects of Composting. In: The science and Engineering of Composting-Part 1. De Bertoldi, M.P. Sequi, B. Lemmes and T. Papi (Eds.), Chapman and Hall, London, England.

23. Hogland, W., T. Bramryd, M. Marques and S. Nimmermark, 2003. Physical, chemical and biological processes for optimizing decentralized small-scale household composting. Compost Science and Utilization, 11: 330-336.

24. Marciniszyn, E. and R. Gottschall, 1999. Process examination to control plant pathogens and weed seed elimination during composting. Proceedings of the Seventh International Waste Management and Landfill Symposium. S. Margherita di Pula, Cagliari, Italy

25. Nobel, R. and S.J. Roberts, 2004. Eradication of plant pathogens and nematodes during composting. Plant Pathol., 53: 548-568. 